\title{
Peraluminous minerals from Chromite layers in the Fiskenæesset Complex, Greenland
}

\author{
S. VENI ${ }^{1 *}$, K. SAJEEV ${ }^{1}$, B.F. WINDLEY ${ }^{2}$
}

${ }^{1}$ Centre for Earth Sciences, Indian Institute of Science,

Bangalore, India (*venisudarsan@iisc.ac.in)

${ }^{2}$ Department of Geology, The University of Leicester,

Leicester, UK

An unusual assemblage of peraluminous minerals $(\mathrm{Crn}+\mathrm{Spr}+\mathrm{Spl})$ occurs in highly calcic anorthosite of the Neoarchean layered megacrystic Fiskenæsset Complex, West Greenland. The spinel grains are enriched in $\mathrm{Al}$ and $\mathrm{Cr}$. Cr-rich spinel (chromite) has compositional zoning due to loss of $\mathrm{Cr}$ and $\mathrm{Fe}$ and gain of $\mathrm{Al}$ towards the rim. However, the chromite core has Cr\# and Fe\# similar to that of other chromites in the Fiskenæsset Complex, which is known for its abundant chromites that have low $\mathrm{Cr} \#(0.405-0.653)$ and high Fe\# (0.614-0.957). Loss of $\mathrm{Cr}$ and $\mathrm{Fe}$ from core to rim indicates the role of chromite in generating Al-rich spinel that has $\sim 7 \mathrm{wt} \%$ of $\mathrm{Cr}$. More than $1 \mathrm{wt} \%$ of $\mathrm{Cr}$ in the sapphirine comes from the controlling chromite.

Plagioclase coronas that contain Al-rich spinel/plagioclase symplectites; these occur along fractures in corundum and sapphirine indicative of late metasomatic reactions. Proximal to chromite is ruby corundum with a sapphirine corona, which in turn is mantled by anorthite; this mineral reaction is explained by:

Corundum $\left(\mathrm{Al}_{2} \mathrm{O}_{3}\right)+$ Plagioclase $\left(\mathrm{CaAl}_{2} \mathrm{Si}_{2} \mathrm{O}_{8}\right) \rightarrow$ Sapphirine ${ }_{\text {corona }}(\mathrm{Mg}, \mathrm{Al}) 8(\mathrm{Al}, \mathrm{Si})_{6} \mathrm{O}_{20}$

The anorthite separates calcic amphibole from sapphirine; the amphibole and plagioclase have similar compositions as those in surrounding chromite-layered anorthosite. These relations suggest that sapphirine and Al-rich spinel formed by metamorphism of highly calcic anorthosite containing chromite. 